Pure Appl. Chem., Vol. 84, No. 6, pp. 1353-1367, 2012.

http://dx.doi.org/10.1351/PAC-CON-11-10-08

(C) 2012 IUPAC, Publication date (Web): 15 April 2012

\title{
Antiproliferative withanolides from the Solanaceae: A structure-activity study*
}

\author{
Huaping Zhang ${ }^{1}$, Abbas K. Samadi ${ }^{2}$, Mark S. Cohen ${ }^{2}$, and \\ Barbara N. Timmermann ${ }^{1, \ddagger}$ \\ ${ }^{1}$ Department of Medicinal Chemistry, School of Pharmacy, University of Kansas, \\ Lawrence, KS 66045, USA; ${ }^{2}$ Department of Surgery, School of Medicine, \\ University of Kansas Medical Center, Kansas City, KS 66160, USA
}

\begin{abstract}
As part of our search for bioactive compounds from plant biodiversity, 29 withanolides were recently isolated from three members of the Solanaceae: Physalis longifolia, Vassobia breviflora, and Withania somnifera. Six derivatives were prepared from these naturally occurring withanolides. All compounds were evaluated for in vitro antiproliferative activity against an array of cell lines [melanoma cell lines (B16F10, SKMEL28); human head and neck squamous cell carcinomas (HNSCC) cell lines (JMAR, MDA1986, DR081-1); breast cancer cell line (Hs578T), and non-malignant human cell line (MRC5)]. This led to the discovery of 15 withanolides, with $\mathrm{IC}_{50}$ values in the range of $0.067-17.4 \mu \mathrm{M}$, including withaferin A, withaferin A 4,27-diacetate, 27-O-glucopyranosylwithaferin A, withalongolide $\mathrm{H}$, withalongolide $\mathrm{C}$, withalongolide $\mathrm{A}$, withalongolide A 4,27-diacetate, withalongolide A 4,19,27-triacetate, withalongolide B, withalongolide B 4-acetate, withalongolide B 4,19-diacetate, withalongolide $\mathrm{D}$, withalongolide $\mathrm{E}$, withalongolide $\mathrm{G}$, and 2,3-dihydrowithaferin A 3-O-sulfate. In order to update the growing literature on withanolides and their activities, we summarized the distribution, structural types, and antiproliferative activities for all published withanolides to date. The structure-activity relationship analysis (SARA) confirmed the importance of the presence of a $\Delta^{2}$-1-oxo-functionality in ring $A$, a $5 \beta, 6 \beta$-epoxy or $5 \alpha$-chloro- $6 \beta$-hydroxy grouping in ring $\mathrm{B}$, and nine-carbon side chain with a lactone moiety for cytotoxic activity. Conversely, the SARA indicated that the $-\mathrm{OH}$ or $-\mathrm{OR}$ groups at C-4, 7, 11, 12, 14, 15, 16, 17, 18, 19, 20, 23, 24, 27, and 28 were not contributors to the observed antiproliferative activity within the systems analyzed.
\end{abstract}

Keywords: antiproliferative; Physalis longifolia; Solanaceae; structure classification; structure-activity relationship; Vassobia breviflora; Withania somnifera; withanolide.

\section{INTRODUCTION}

The name "withanolides" was originally given to a family of $\mathrm{C}_{28}$ ergostane-type steroidal $\delta$-lactones (derived from a parent 22-hydroxy-26-oic acid) isolated from the genus Withania (Solanaceae). The term "withan" refers to Withania and "-olide" to the presence of lactone functionality in this type of compound. With the structural elucidation of withaferin A 1 (Fig. 1) in 1965, a new area of withanolide chemistry was initiated [1]. Further investigations in this field led to the discovery of many hun-

*Pure Appl. Chem. 84, 1297-1478 (2012). A collection of invited papers based on presentations at the $27^{\text {th }}$ International Symposium on the Chemistry of Natural Products and the $7^{\text {th }}$ International Conference on Biodiversity (ISCNP-27 \& ICOB-7), Brisbane, Australia, 10-15 July 2011.

¥Corresponding author: Tel.: +01-785-864-4844; Fax: +01-785-864-5326; E-mail: btimmer@ku.edu 

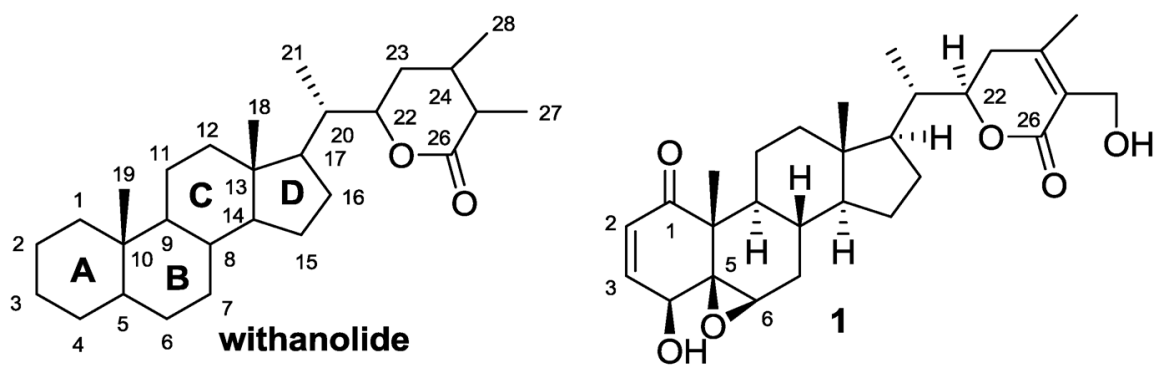

Fig. 1 Withanolide carbon-frame and structure of withaferin A 1.

dreds of additional compounds, which include 22 related but different structural types such as: (1) new withanolides exhibiting $\gamma$-lactone functionality (from 23-hydroxy-26-oic or 28-hydroxy-26-oic acids), or $\gamma$-lactol functionality (from 28-hydroxy-26-als), or $\delta$-lactol functionality (from 22-hydroxy-26-als) in the side chain (Fig. 2); (2) new withanolides isolated from sources other than the genus Withania (Table 1); and (3) a number of structural varieties with novel skeletons derived or modified from, or biogenetically related to, the highly oxygenated withanolides by ring fission, cyclization, and skeleton rearrangements in either or both of the steroid nucleus and in the nine-carbon side chain [2-8]. In view of these findings, the original term "withanolide" is no longer limited to its primary definition, and it has expanded to encompass the structurally diverse variants bearing different carbon scaffolds, such as those present in acnistin, joborol, neophysalin, nicandrenone, physalin, taccalonolide, and withajardin (Fig. 2).

In recent years, withanolides have held the interest of the scientific community owing to their structural features and display of significant pharmacological activities-antimicrobial, antitumor, antiinflammatory, immunomodulatory, and insect-antifeedant [2-4,9]. Over the last 46 years, approximately 750 withanolides, exhibiting more than 22 carbon skeletons (Fig. 2), have been reported from various plant sources. As listed in Table 1, withanolides are predominant in 25 genera (including Acnistus, Datura, Deprea, Discopodium, Dunalia, Iochroma, Jaborosa, Lycium, Nicandra, Physalis, Solanum, Trechonaetes, Tubocapsicum, Vassobia, Withania, and Witheringia) of the Solanaceae family [2-7,10-12]. Not limited to the Solanaceae, withanolides have also been isolated from a smaller number of species in the Dioscoreaceae [13], Fabaceae [7], Lamiaceae [2], Myrtaceae [14], Taccaceae [2], and from two genera in the marine Alcyoniidae $[15,16]$. Although the large family Solanaceae is composed of six subfamilies, with the exception of Browallia viscosa, all species containing withanolides belong to the subfamily Solanoidea [3,4]. Within the Solanoideae Jaborosa, Physalis, and Withania have been the genera most extensively studied to date. For example, more than 130 withanolides with diversified functional groups were isolated from different parts (whole plant, aerial parts, flowers, fruits, leaves, roots, and stem barks) of Withania somnifera, a traditional plant of wide use in Ayurvedic medicine. This plant contains the largest number of withanolides reported from any one species so far. All the withanolides from Withania possess only a type Ia skeleton (Fig. 2), while those reported from Physalis show greater variety with more than 10 structural types (Fig. 2 and Table 1). 


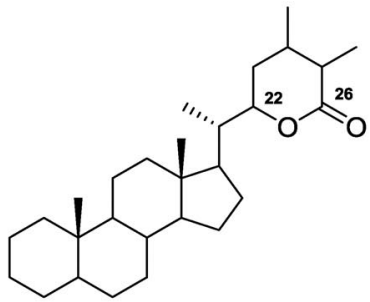

la withanolide

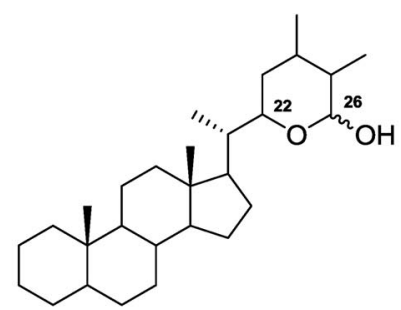

Ib

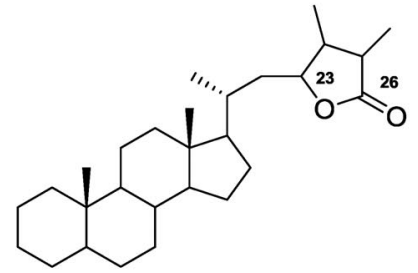

Ic

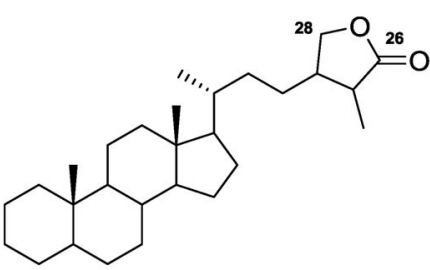

Id

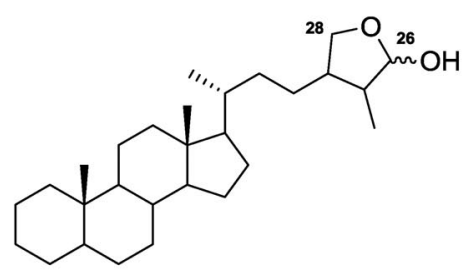

le

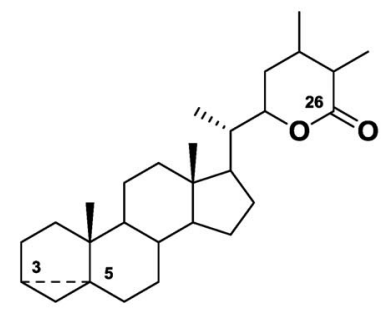

II

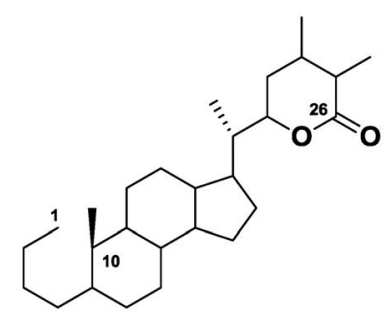

III

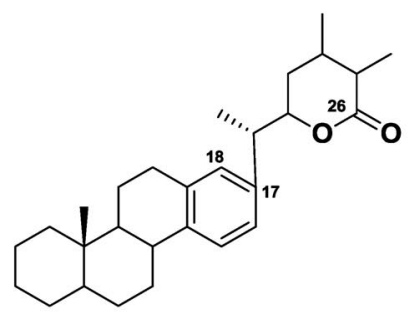

VI nicandrenone

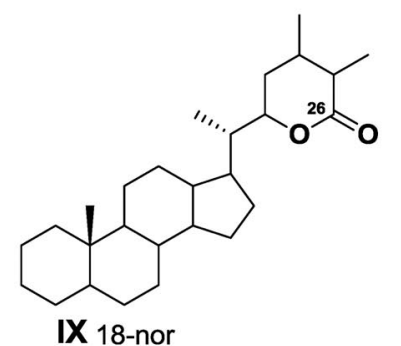

Fig. 2 Twenty-two structure types of withanolides based on their carbon skeletons (1965-2011).

(continues on next page)

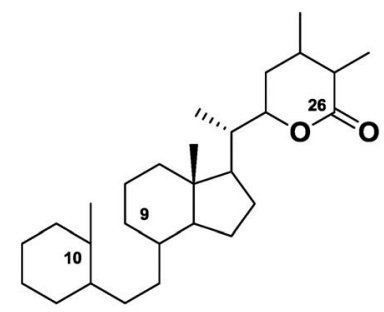

IV jaborol<smiles>CC1C[C@H]([C@H](C)C2(C)CCC3C4CCC5CCCC[C@]5(C)C4CCC32)OC(=O)C1C</smiles>

VII

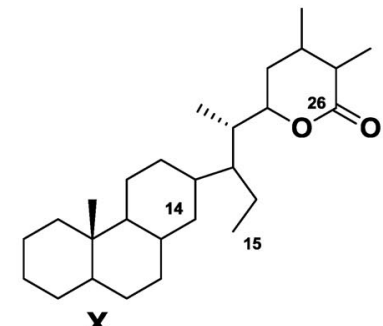

$\mathbf{X}$

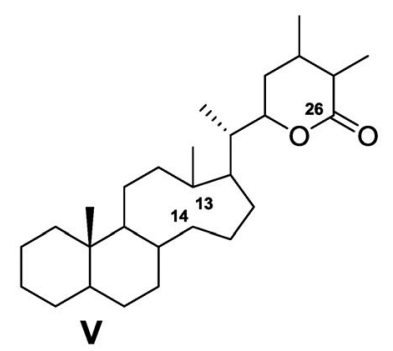<smiles>CC1C[C@H]([C@H](C)C2CCC3C4CCC5CCCCC5C4CC[C@@]32C)OC(=O)C1C</smiles>

VIII 19-nor

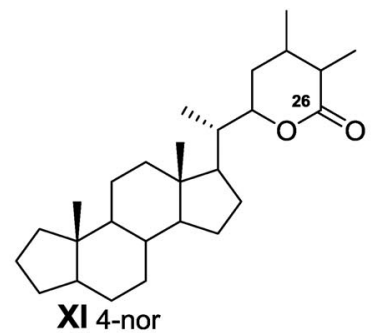




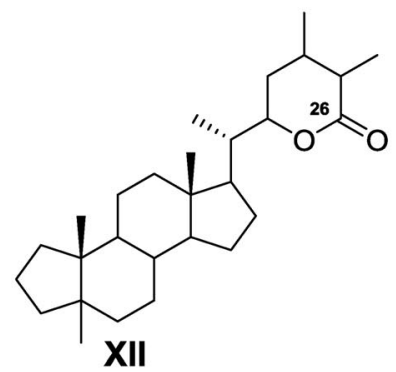

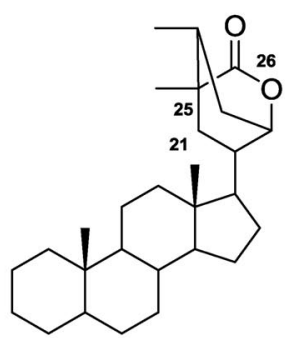

$\mathbf{X V}$ withajardin

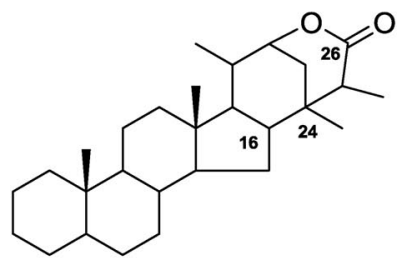

XVIII taccalonolide

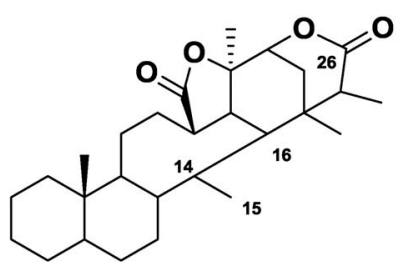

XXI neophysalin

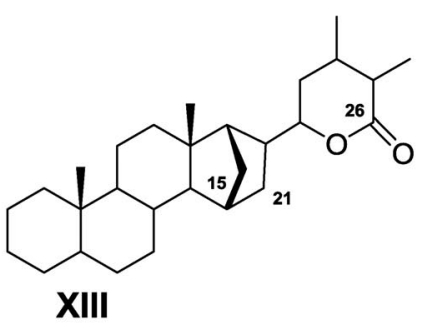

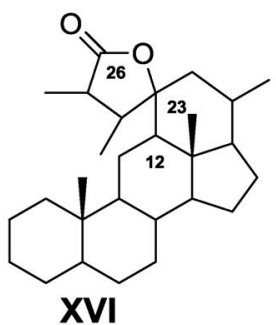

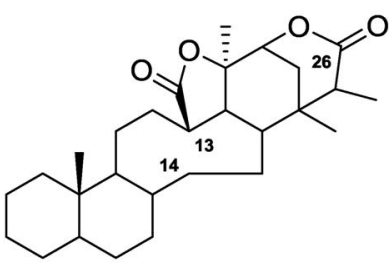

XIX physalin

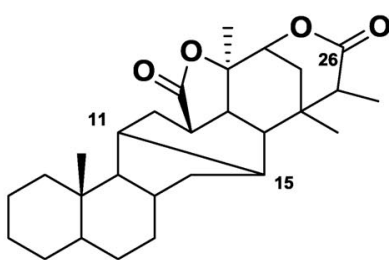

XXII

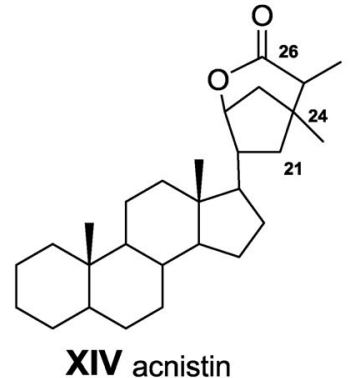<smiles>CC1CCC2COC(=O)[C@@]2(C)[C@@H]2C[C@H]3C4CCC5CCCC[C@]5(C)C4CC[C@]3(C)[C@H]12</smiles>

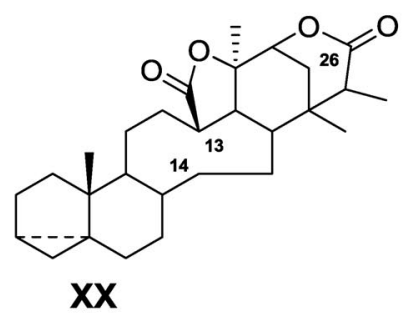

Fig. 2 (Continued).

Type I withanolides (Fig. 2), also called unmodified withanolides, are the most abundant form found in nature. With approximately 540 compounds in this category reported to date, they are distributed in the majority of the genera listed in Table 1. From the biogenetic origin, it is likely that type I compounds are precursors to the more advanced structural types II-XXII. Type I withanolides that display the most promising antiproliferative characteristics also contain $\Delta^{2}$-1-oxo-functionality in ring $\mathrm{A}$, a $5 \beta, 6 \beta$-epoxy-group in ring $\mathrm{B}$, and a nine-carbon side chain incorporating the $\delta$-lactone functionality found in withaferin A 1 [17], withacnistin 59 [18,19], withanolide D 48 [20-23], withanolide E 36 [8,24-27], and 43-hydroxywithanolide E 37 (Fig. 4) [8,24-27]. Withaferin A 1 (Fig. 1) was shown to induce apoptosis in vitro and in vivo by suppressing the growth of an array of tumor cells, including 
Table 1 Sources of withanolides and their corresponding structure types.

\begin{tabular}{|c|c|c|c|}
\hline Family & & Species & Structure type \\
\hline \multirow[t]{25}{*}{ Solanaceae } & 1 & $\begin{array}{l}\text { Acnistus arborescens, A. australis, A. breviflorus, A. lorentzii, } \\
\text { A. ramiflorus }\end{array}$ & I, XIV \\
\hline & 2 & Aureliana fasciculata $[10]$ & I \\
\hline & 3 & Brachistus stramoniifolius & I \\
\hline & 4 & Browallia viscosa & $\mathrm{I}, \mathrm{VI}$ \\
\hline & 5 & $\begin{array}{l}\text { Datura fastuosa, D. ferox, D. innoxia, D. metel, D. quercifolia, } \\
\text { D. stramonium, D. tatula }\end{array}$ & I, III \\
\hline & 6 & Deprea orinocensis, $D$. subtriflora & I, IX, XV \\
\hline & 7 & Discopodium pernninervivum & I, XIV \\
\hline & 8 & $\begin{array}{l}\text { Dunalia arborescens, D. australis, D. brachyacantha, D. solanacea, } \\
\text { D. tubulosa }\end{array}$ & I, XIV \\
\hline & 9 & Exodeconus maritimus & I \\
\hline & 10 & Hyoscyamus niger, $H$. muticus & I \\
\hline & 11 & Iochroma australe, I. coccineum, I. fuchsiodies, I. gesnerioides & I \\
\hline & 12 & $\begin{array}{l}\text { Jaborosa araucana, J. bergii, J. caulescens, J. integrifolia, } \\
\text { J. kurtzii, J. laciniata, J. lanigera, J. leucotricha, J. magellanica, } \\
\text { J. odonelliana, J. parviflora, J. rotacea, J. runcinata, J. sativa }\end{array}$ & I, IV, VIII, XIII, XVI \\
\hline & 13 & Larnax glabra [11] & I \\
\hline & 14 & Lycium chinense, L. halimifolium & I \\
\hline & 15 & Mandragora officinarum [12] & I, XIV \\
\hline & 16 & Nicandra physaloides & I, VI \\
\hline & 17 & 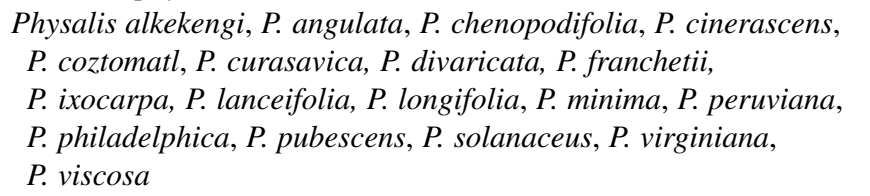 & $\begin{array}{l}\text { I, III, V, VIII, XI, } \\
\text { XVII, XIX, XX, } \\
\text { XXI, XXII }\end{array}$ \\
\hline & 18 & Salpichroa origanifolia & I, VI \\
\hline & 19 & Saracha viscosa & XIX \\
\hline & 20 & Solanum ciliatum, S. sisymbrifolium & I, II \\
\hline & 21 & Trechonaetes laciniata & I \\
\hline & 22 & Tubocapsicum anomalum & I, VII, XIV, XV \\
\hline & 23 & Vassobia lorentzii, V. breviflora & I \\
\hline & 24 & $\begin{array}{l}\text { Withania adpressa, W. aristata, W. coagulans, W. frutescens, } \\
\text { W. obtusifolia, W. somnifera }\end{array}$ & I \\
\hline & 25 & Witheringia coccoloboides, W. hunzikeri, W. solanacea & XIX \\
\hline Dioscoreaceae & & Dioscorea japonica [13] & I \\
\hline Fabaceae & & Cassia siamea & I \\
\hline Lamiaceae & & Ajuga parviflora, A. bracteosa & I \\
\hline Myrtaceae & & Eucalyptus globulus [14] & I \\
\hline Taccaceae & & $\begin{array}{l}\text { Tacca chantrieri, T. integrifolia, T. paxiana, T. plantaginea, } \\
\text { T. subflabellata }\end{array}$ & I, XVIII \\
\hline Alcyoniidae & & Paraminabea acronocephala, Minabea sp. (soft coral) $[15,16]$ & I \\
\hline
\end{tabular}

breast, pancreatic, prostate, lung, leukemia, as well as various head and neck squamous cell carcinomas (HNSCCs) [17]. This compound has the potential for development as an antiproliferative agent.

As part of our continuing investigations to discover drug leads from plant biodiversity, we have explored the antiproliferative potential of compounds present in several members of the large family Solanaceae. An approach of in vitro MTS cytotoxicity bioassay of Physalis longifolia Nutt., Vassobia breviflora (Sendtn.) Hunz, and Withania somnifera (L.) Dunal led to the identification of bioactive withanolides. A panel of HNSCC cells (JMAR, MDA1986, and DR081-1), melanoma cells (B16F10 and 

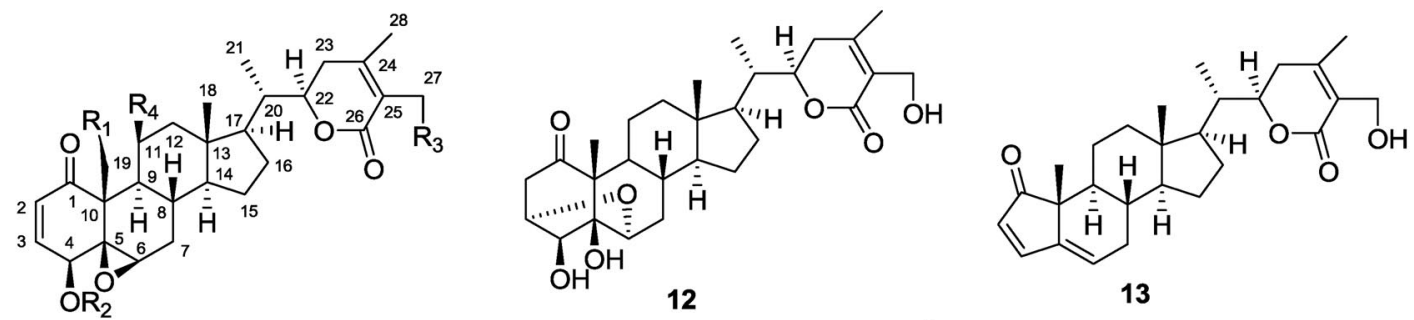

12

13

$1 \quad R_{1}=R_{2}=R_{4}=H \quad R_{3}=O H$

$2 \quad \mathrm{R}_{1}=\mathrm{R}_{4}=\mathrm{H} \quad \mathrm{R}_{2}=\mathrm{AC} \quad \mathrm{R}_{3}=\mathrm{OAC}$

$3 \quad \mathrm{R}_{1}=\mathrm{R}_{2}=\mathrm{R}_{4}=\mathrm{H} \quad \mathrm{R}_{3}=$ Oglc

$4 \quad R_{1}=R_{2}=R_{4}=H \quad R_{3}=$ Oglc- $(1 \rightarrow 4)$-rha

$5 \quad R_{1}=R_{2}=H \quad R_{3}=R_{4}=O H$

$6 \quad \mathrm{R}_{1}=\mathrm{R}_{3}=\mathrm{OH} \quad \mathrm{R}_{2}=\mathrm{R}_{4}=\mathrm{H}$

$\begin{array}{lllll}7 & \mathrm{R}_{1}=\mathrm{OH} & \mathrm{R}_{2}=\mathrm{Ac} & \mathrm{R}_{3}=\mathrm{OAC} & \mathrm{R}_{4}=\mathrm{H}\end{array}$

$8 \mathrm{R}_{1}=\mathrm{R}_{3}=\mathrm{OAC} \quad \mathrm{R}_{2}=A C \quad \mathrm{R}_{4}=\mathrm{H}$

$9 \quad \mathrm{R}_{1}=\mathrm{OH} \quad \mathrm{R}_{2}=\mathrm{R}_{3}=\mathrm{R}_{4}=\mathrm{H}$

$10 \mathrm{R}_{1}=\mathrm{OH} \quad \mathrm{R}_{2}=A C \quad \mathrm{R}_{3}=\mathrm{R}_{4}=\mathrm{H}$

$11 R_{1}=O A c \quad R_{2}=A c \quad R_{3}=R_{4}=H$

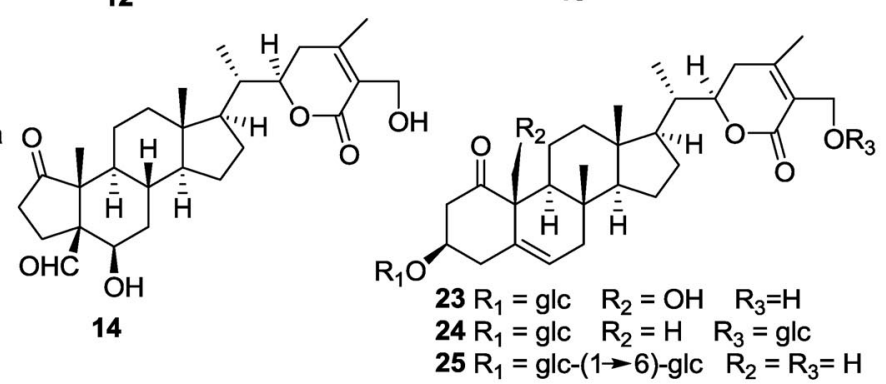

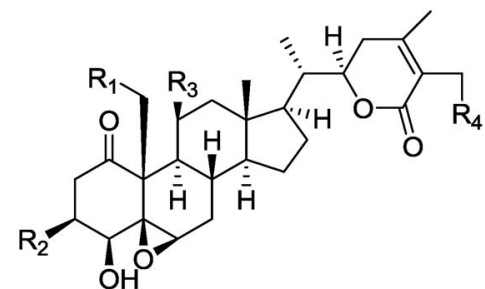

$15 \quad \mathrm{R}_{1}=\mathrm{H} \quad \mathrm{R}_{2}=\mathrm{OCH}_{3} \quad \mathrm{R}_{3}=\mathrm{R}_{4}=\mathrm{OH}$

$16 \mathrm{R}_{1}=\mathrm{R}_{4}=\mathrm{OH} \quad \mathrm{R}_{2}=\mathrm{OCH}_{3} \quad \mathrm{R}_{3}=\mathrm{H}$

$17 \quad \mathrm{R}_{1}=\mathrm{R}_{3}=\mathrm{H} \quad \mathrm{R}_{2}=\mathrm{OCH}_{3} \quad \mathrm{R}_{4}=\mathrm{OH}$

$18 \quad R_{1}=R_{2}=R_{3}=H \quad R_{4}=O H$

$19 \quad R_{1}=R_{2}=R_{3}=R_{4}=H$

$20 \quad \mathrm{R}_{1}=\mathrm{R}_{3}=\mathrm{H} \quad \mathrm{R}_{2}=\mathrm{R}_{4}=\mathrm{OH}$

$21 \quad \mathrm{R}_{1}=\mathrm{R}_{4}=\mathrm{OH} \quad \mathrm{R}_{2}=\mathrm{OSO}_{3} \mathrm{H} \quad \mathrm{R}_{3}=\mathrm{H}$

$22 \quad R_{1}=R_{3}=H \quad R_{2}=O_{3} O_{3} H \quad R_{4}=O H$

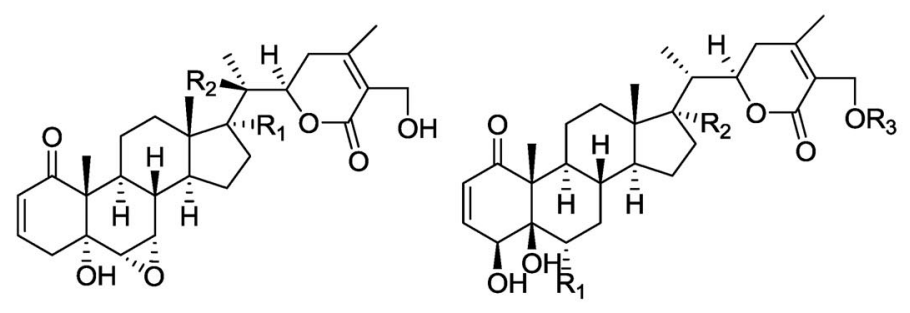

$26 \mathrm{R}_{1}=\mathrm{OH} \quad \mathrm{R}_{2}=\mathrm{H}$

$27 \mathrm{R}_{1}=\mathrm{H} \quad \mathrm{R}_{2}=\mathrm{OH}$
$28 \mathrm{R}_{1}=\mathrm{Cl} \quad \mathrm{R}_{2}=\mathrm{OH}$

$29 \mathrm{R}_{1}=\mathrm{Cl} \quad \mathrm{R}_{2}=\mathrm{H}$

$30 \mathrm{R}_{1}=\mathrm{OH} \mathrm{R}_{2}=\mathrm{H}$

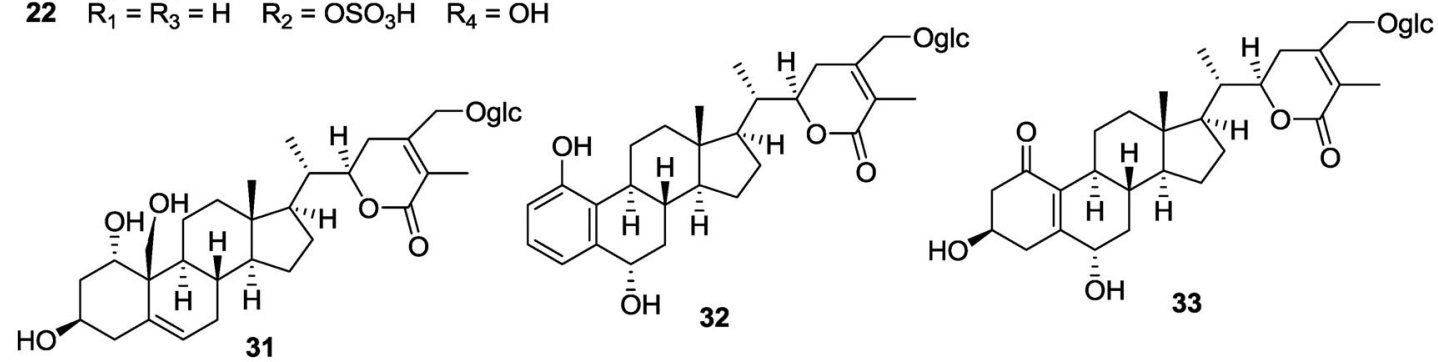
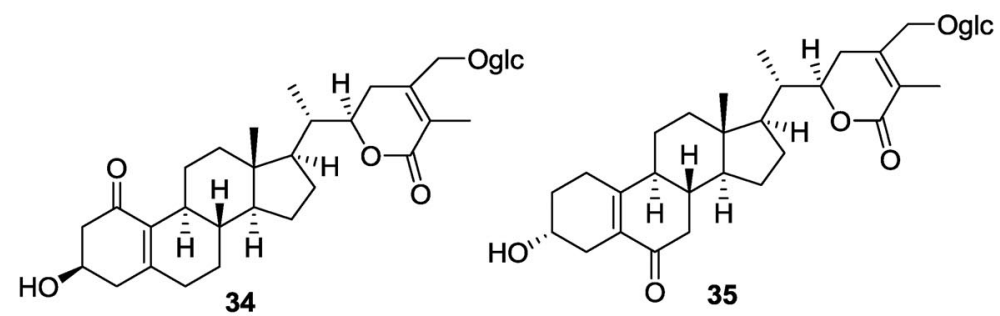

Fig. 3 Withanolides (1, 3-6, 9, 12-18, and 20-35) from Physalis longifolia, Vassobia breviflora, and Withania somnifera and their derivatives $(\mathbf{2}, \mathbf{7}, \mathbf{8}, \mathbf{1 0}, \mathbf{1 1}$, and 19) $[17,28,29]$. 
SKMEL28), and/or, human breast cancer cell lines (Hs578T) and non-malignant human renal epithelial cell line (MRC5) were used to evaluate the extracts/fractions/compounds. This work resulted in the isolation and characterization of 35 withanolides (1-35, Fig. 3). Of these, 29 withanolides $(\mathbf{1}, \mathbf{3 - 6}, \mathbf{9}$, 12-18, and 20-35) were isolated from the three taxa investigated whereas the remaining six analogues $(2,7,8,10,11$, and 19) were prepared from the naturally occurring compounds $(\mathbf{1}, \mathbf{6}$, and 9$)$. In this report, we provide a summary of the withanolide chemistry and anti proliferative results obtained during our studies $[17,28,29]$ and attempt to provide a structure-activity relationship analysis (SARA) in comparison with published data in the literature for other withanolides with antiproliferative activity.

\section{RESULTS AND DISCUSSION}

Our own investigation of selected members of the Solanaceae afforded withanolides 1, 20, and 22 from the aerial parts of Vassobia breviflora [17], withanolides 1, 14, 17, 18, and 24-30 from the leaves of Withania somnifera [28], as well as withanolides 1, 3-6, 9, 12, 13, 15-18, 20-23, and 31-35 from the aerial part of Physalis longifolia [29]. The acetate derivatives $\mathbf{7}$ and $\mathbf{8}$ were prepared from withalongolide A 6; compounds 10 and 11 were obtained from withalongolide B 9 while compounds 2 and 19 were derived from withaferin A $\mathbf{1}$. Withanolides 13-17 are likely to be artifacts formed during the isolation process. The structures of 1-35 were determined by electrospray ionization-mass spectrometry (ESI-MS) and 2D NMR experiments while those of 5, 6, 9, 13, 19, and 28 [28,29] were confirmed by $\mathrm{X}$-ray crystallographic analysis.

Based on their carbon skeletons, the withanolides isolated by our group can be assigned to four structural types with various degrees of oxygenation: type I (1-12, and 15-30), type VIII (31-35), type XI (13), and type XII (14). All the compounds show the commonly oxygenated carbons at C-1, 22, and 26 except compound $\mathbf{3 5}$ which lacks an oxygenated C-1. Further oxygenated positions can occur at C-3 (12, 15-17, 20-25, 31, and 33-35), C-4 (1-12, 15-22, and 28-30), C-5 and C-6 in the form of an epoxygroup (1-11 and 15-22), C-6 and C-7 in the form of an epoxy-group (26 and 27), C-11 (5 and 15), C-17 (26 and 28), C-19 (6, 9, 16, 21, 23, and 31), C-20 (27), C-27 (1-8, 12-18, and 20-30), and C-28 (31-35). In addition, withanolides 21 and 22 occur as 3-O-sulfates, while withanolides 3, 4, 23-25, and 31-35 occur as withanolide saponins with one or two sugar residues and withanolides 28 and 29 are chlorinated at C-6.

All 35 withanolides isolated during our studies were tested against the HNSCC cells (JMAR, MDA1986, and DR081-1), melanoma cells (B16F10 and SKMEL28), and/or breast cancer cells (Hs578T) as well as non-malignant human renal epithelial cells (MRC5) for their in vitro antiproliferative activities. Cisplatin was used as a positive control. The results, expressed as $\mathrm{IC}_{50}(50 \%$ inhibition of cell growth), are summarized in Table 2. Overall, 15 withanolides (1-11, 16-17, and 21-22) including the five acetate derivatives $(\mathbf{2}, \mathbf{7}, \mathbf{8}, \mathbf{1 0}$, and 11) showed antiproliferative effects against the cells tested with $\mathrm{IC}_{50}$ values in the range $0.067-17.4 \mu \mathrm{M}$, while the other withanolides were inactive when tested at the higher concentration of $20 \mu \mathrm{M}$. A preliminary structure-activity relationship (SAR) could be inferred based on the assay data obtained. 
Table $2 \mathrm{IC}_{50}$ values $(\mu \mathrm{M})$ of withanolides (natural and derivatives) against six cell lines [17,29].

\begin{tabular}{|c|c|c|c|c|c|c|c|c|}
\hline Withanolide & Description & $\mathrm{B} 16 \mathrm{~F} 10$ & SKMEL28 & JMAR & MDA1986 & DR081-1 & MRC5 & Hs578T \\
\hline 1 & Withaferin A & 0.29 & 3.96 & 2.0 & 0.80 & 1.09 & 0.20 & 1.19 \\
\hline 2 & Withaferin A 4,27-diacetate & 0.15 & 0.11 & 0.19 & 0.32 & 0.76 & - & - \\
\hline 3 & 27-O-Glucopyranosylwithaferin A & 3.65 & 8.3 & 4.20 & NA & NA & 5.24 & 8.79 \\
\hline 4 & 4'-O-Rhamnosyl 3 & NA & 17.4 & 8.24 & 8.1 & NA & 8.72 & 11.08 \\
\hline 5 & 11ß-Hydroxywithaferin A & 0.49 & 2.99 & 0.77 & 2.64 & 5.46 & 3.60 & 2.47 \\
\hline 6 & 19-Hydroxywithaferin A & 11.1 & 5.06 & 5.32 & 3.34 & 2.37 & 12.7 & 2.22 \\
\hline 7 & 6 4,27-Diacetate & 0.098 & 0.81 & 0.14 & 2.24 & 1.28 & 0.41 & 0.46 \\
\hline 8 & $64,19,27$-Triacetate & 0.067 & 0.54 & 0.16 & 0.91 & 0.29 & 0.58 & 0.32 \\
\hline 9 & 27-Deoxy-6 & 0.2 & 3.91 & 0.17 & 1.3 & 0.90 & 0.40 & 0.47 \\
\hline 10 & 9 4-Acetate & 0.19 & 0.64 & 0.12 & 0.49 & 0.96 & 0.16 & 0.43 \\
\hline 11 & 9 4,19-Diacetate & 0.13 & 0.27 & 0.24 & 0.11 & 0.54 & 0.51 & 0.26 \\
\hline 16 & 2,3-Dihydro-3-methoxy-6 & 3.21 & 9.27 & 4.69 & NA & 5.84 & 6.5 & 8.43 \\
\hline 17 & 2,3-Dihydro-3-methoxy-5 & 5.57 & 11.6 & 12.0 & 8.34 & NA & 7.33 & - \\
\hline 21 & 2,3-Dihydro-6 3-O-sulfate & 1.33 & 4.8 & 2.25 & 2.02 & NA & 3.33 & 3.4 \\
\hline 22 & $\begin{array}{l}\text { 2,3-Dihydrowithaferin A } \\
\text { 3-O-sulfate }\end{array}$ & 0.18 & 5.12 & 0.48 & 0.27 & 2.46 & 1.35 & 1.16 \\
\hline Cisplatin & Positive control & 1.0 & 1.07 & 1.12 & 1.62 & - & 8.90 & - \\
\hline
\end{tabular}

Note: Cell lines include melanoma cell lines (murine B16F10 and human SKMEL28), HNSCC cell lines (JMAR, MDA1986, and DR081-1), non-malignant human renal epithelial cell line (MRC5), and breast cancer cell line (Hs578T); - not tested; NA: no activity, meaning $\mathrm{IC}_{50}>20 \mu \mathrm{M}$.

Direct comparison revealed that opening of the $5 \beta, 6 \beta$-epoxy-group of withaferin A 1 to furnish the corresponding $5 \beta, 6 \alpha$-diol 29 or $6 \alpha$-chloro- $5 \beta$-ol 30 resulted in loss of activity. These findings confirm that the $5 \beta, 6 \beta$-epoxy-group in ring $\mathrm{B}$ is essential for the observed cytotoxic activity, in agreement with results previously reported in the literature for compounds with similar structural features [25-27].

Withanolides 15-22 contain a 5 $\beta, 6 \beta$-epoxy-group in ring B but lack a $\Delta^{2}-1$-oxo-system in ring A. A loss of activity was observed when this latter feature is absent, by comparing activity of withaferin A 1 with 2,3-dihydrowithaferin A 18 or 2,3-dihydro-27-deoxywithaferin A 19, or 2,3-dihydro-3 $\beta$ hydroxywithaferin A 20. A decrease of activity was also observed when $\Delta^{2}-1$-oxo-functionality was replaced with a 2,3-dihydro-3 $\beta$-methoxy moiety, by comparing withaferin A 1 with 2,3-dihydro-3 $\beta$ methoxywithaferin A 17, and withalongolide B 5 with 2,3-dihydro-3 $\beta$-methoxywithalongolide C 15. On the other hand, the activity observed for 2,3-dihydrowithalongolide A $3 \beta$-O-sulfate 21 and 2,3-dihydrowithaferin A $3 \beta-O$-sulfate 22 was likely due to their spontaneous conversion in the cell culture media to the corresponding withalongolide A $\mathbf{6}$ and withaferin A 1, both compounds having $\Delta^{2}$-1-oxo-functionality [30]. Our data thus confirm the significance of the presence of this ring A feature for the observed cytotoxic activity and are in agreement with results available in the literature $[24,26]$.

As in the case of withaferin A 1, withanolides 2-11 with identical functionality in rings A and B were also active, further supporting the significance of this functional array. In contrast, withanolides 12-14 and 23-35, in which it is absent, were shown to be inactive.

Furthermore, withaferin A 1, 27-O-glucopyranosylwithaferin A 3, and 27-O-[ $\alpha$-L-rhamnopyra$\operatorname{nosyl}(1 \rightarrow 4)$ ]-glucopyranosylwithaferin A 4 , in which the combination of $5 \beta, 6 \beta$-epoxy- and $\Delta^{2}-1$-oxofunctionality is retained, showed different activities against the cells tested. Withanolide glycoside $\mathbf{3}$ with one sugar residue was less active relative to the aglycone $\mathbf{1}$, while withanolide saponin $\mathbf{4}$ with two sugar residues displayed less cytoxicity when compared to $\mathbf{3}$. This observation suggested that glycosylation of withanolides resulted in a decrease of cytotoxic activity. On the other hand, esterification of the hydroxyl groups at C-4, C-19, and C-27 increased cytotoxicity when comparing withaferin A $\mathbf{1}$ with withaferin A 4,27-diacetate 2; withalongolide A 6 with withalongolide A 4,27-diacetate 7 and withalongolide A 4,19,27-triacetate 8; withalongolide B 9 with withalongolide B 4-acetate $\mathbf{1 0}$ and withalon- 
golide B 4,19-diacetate 11 (Table 2). These results are in agreement with previously reported SARs [24-27,31]. It should be noted that the cytotoxic activity of withalongolide B $\mathbf{9}$ is comparable to that of withaferin A 1, while the triacetate derivative $\mathbf{8}$ and diacetate derivative $\mathbf{1 1}$ are more potent than withaferin $\mathrm{A} \mathbf{1}$ by exhibiting submicromolar activity with $\mathrm{IC}_{50}$ values in the range of $0.067-0.91 \mu \mathrm{M}$ against all the cell lines tested.

All withanolides so far discovered can be generally defined as poly-oxygenated steroids with all their carbon atoms bearing oxygen functions except for C-8 and C-10. Scattered throughout the literature, it is apparent by qualitative measures, that the -OH or -OR groups do not contribute to the antiproliferative ability of the active withanolides. This characteristic has been observed with different cell lines used in the evaluation of cytotoxicity for this type of compound. Various withanolides containing hydroxyl groups at different positions were assembled from the literature (Fig. 4) and listed in Table 3 for a comparison of their respective cytotoxic activities. It is clear from these data that hydroxy- or acetoxy-groups at C-4, 7, 11, 12, 14, 15, 16, 17, 18, 19, 20, 23, 24, and 27 have no significant effect on their cytotoxic activity. In most cases, withanolides possessing hydroxyl groups at such positions are slightly less potent than those without this functional group. The results of the analysis based on our own data as well as those obtained from the literature (Table 3) are summarized below, taking into consideration different functional groups in the withanolide molecules:

4-OH group: The presence of a $4 \beta$-hydroxy-group is not required for the cytotoxic activity when comparing the activity of withanolide E $\mathbf{3 6}$ and $4 \beta$-hydroxywithanolide E 37 [24,26,27]; 4-deoxy-7,16diacetoxywithanolide D 39 and 7,16-diacetoxywithanolide D 40 [32]; 4-deoxyphysagulin C 42 and physagulin C 43 [33]; 4-deoxywithangulatin A 44 and withangulatin A 45 [33]; acnistin A 46 and 4-hydroxyacnistin E 47 [34]. In most cases, the 4-hydroxywithanolides are slightly less potent than the corresponding 4-deoxywithanolides.

7-OAc group: The presence of $7 \beta$-acetoxy-group had essentially no effect on the cytotoxic activity when comparing the activity of withanolides D 41 and $\mathbf{4 0}$ [32].

11-OH group: 11 $\beta$-Hydroxywithaferin A $\mathbf{5}$ is slightly less potent than withaferin A $\mathbf{1}$ (Table 2).

12-OH group: $12 \beta$-Hydroxywithanolide D 49 is slightly less potent than withanolide D 48 [22].

14,15-epoxy-group: $14 \alpha, 15 \alpha$-Epoxywithaferin A $\mathbf{5 0}$ is less potent than withaferin A 1 [35].

16-OH group: $16 \alpha$-Hydroxyanomanolide A 52 is slightly less potent than anomanolide A $\mathbf{5 1}$ [36].

16-OAc group: 7 $\beta, 16 \alpha$-Diacetoxywithanolide D 40 is slightly less potent than $7 \beta$-acetoxywithanolide D $41[32,37]$.

16,17-epoxy-group: $16 \alpha, 17 \alpha$-Epoxywithaolide D 55 is slightly less potent than withanolide D $48[36]$.

17-OH group: $17 \alpha$-Hydroxywithanolide D 56 is slightly less potent than withanolide D 48 [36].

18-OAc group: 18-Acetoxy-27-deoxywithaferin A $\mathbf{5 8}$ is comparable to withaferin A 1 [18].

19-OH group: 19-Hydroxywithaferin A 6 is less potent than withaferin A 1. 2,3-dihydro-19hydroxywithaferin A $3 \beta-O$-sulfate 22 is less potent than 2,3-dihydrowithaferin A $3 \beta$-O-sulfate 21. 4,27-Diacetoxy-19-hydroxywithaferin A 7 is comparable to 4,27-diacetoxywithaferin A 2 (Table 2). In most cases, the 19-hydroxywithanolides are slightly less potent than the corresponding 19-deoxywithanolides.

20-OH group: 20-Hydroxytubocapsanolide F 56 is comparable to tubocapsanolide F 57 while 20-hydroxytubocapsanolide A $\mathbf{5 5}$ is slightly less potent than tubocapsanolide A $\mathbf{5 3}$ [36].

23-OH group: 23-Hydroxytubocapsanolide A 54 is slightly less potent than tubocapsanolide A $53[36]$.

24-OH group: 24-Hydroxywithaphysacarpin 60 is less potent than withaphysacarpin $\mathbf{5 9}$ [38].

27-OH group: 27-Hydroxy withalongolide B 6 is less potent than withalongolide B 9 (Table 2).

It should be noted that although there are several 21-hydroxywithanolides (mainly isolated from Datura [39] and Jaborosa [5]) and 28-hydroxywithanolides reported in the literature, their antiprolifer- 


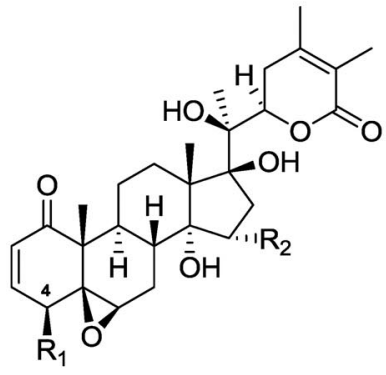

$36 \mathrm{R}_{1}=\mathrm{H} \quad \mathrm{R}_{2}=\mathrm{H}$

$37 \mathrm{R}_{1}=\mathrm{OH} \mathrm{R} \mathrm{R}_{2}=\mathrm{H}$

$38 \mathrm{R}_{1}=\mathrm{OH} \mathrm{R} \mathrm{R}_{2}=\mathrm{OH}$
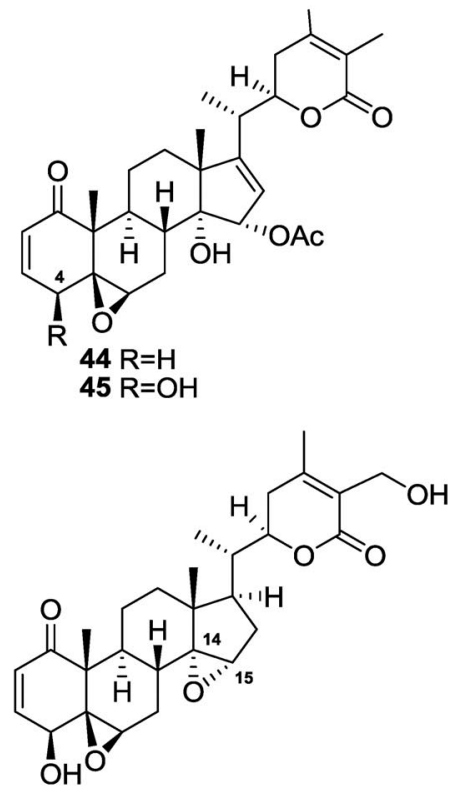

50

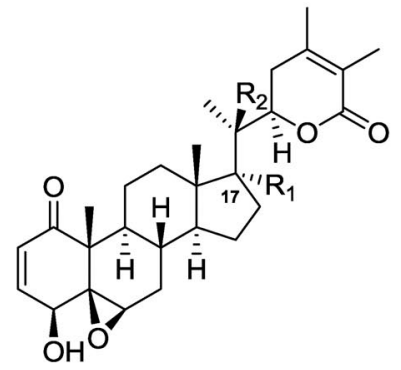

$56 \mathrm{R}_{1}=\mathrm{OH} \mathrm{R} \mathrm{R}_{2}=\mathrm{OH}$ $57 \mathrm{R}_{1}=\mathrm{OH} \mathrm{R} \mathrm{R}_{2}=\mathrm{H}$

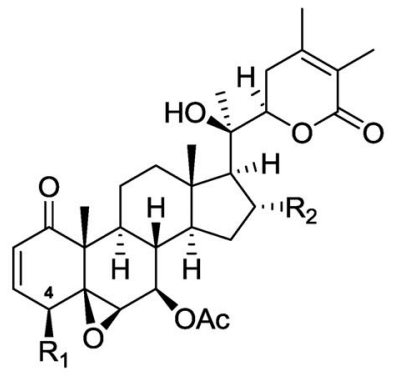

$39 \mathrm{R}_{1}=\mathrm{H} \quad \mathrm{R}_{2}=\mathrm{OAC}$

$40 \mathrm{R}_{1}=\mathrm{OH} \mathrm{R} \mathrm{R}_{2}=\mathrm{OAC}$

$41 \mathrm{R}_{1}=\mathrm{OH} \mathrm{R} \mathrm{R}_{2}=\mathrm{H}$
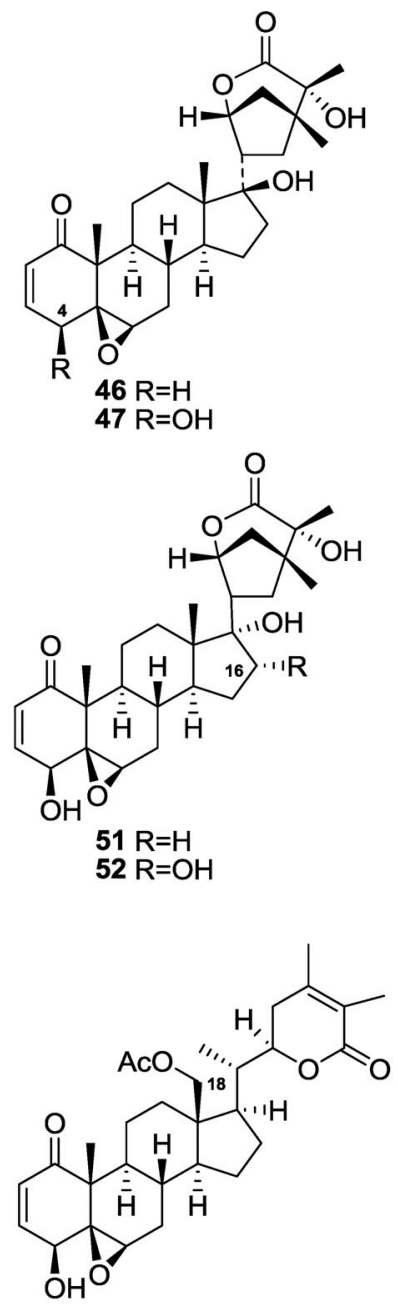

58

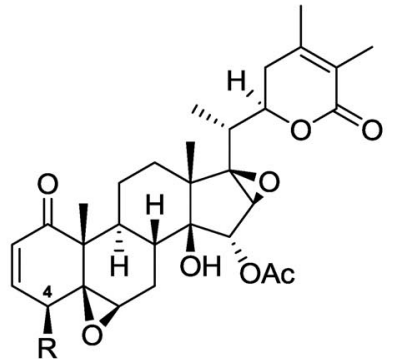

$42 \mathrm{R}=\mathrm{H}$

$43 \mathrm{R}=\mathrm{OH}$

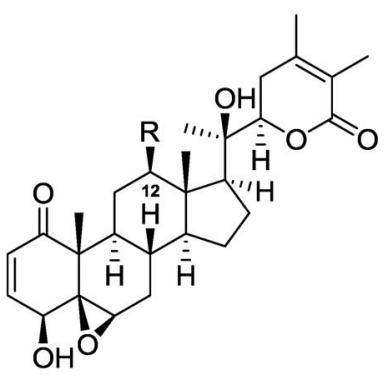

$48 \mathrm{R}=\mathrm{H}$

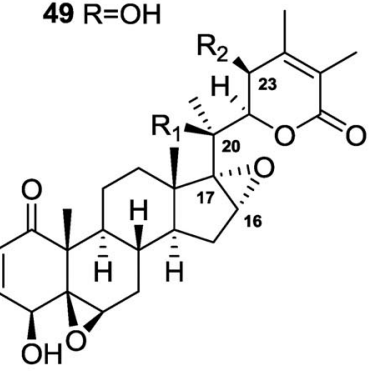

$53 \mathrm{R}_{1}=\mathrm{H} \quad \mathrm{R}_{2}=\mathrm{OH}$

$54 \mathrm{R}_{1}=\mathrm{OH} \mathrm{R} \mathrm{R}_{2}=\mathrm{OH}$

$55 \mathrm{R}_{1}=\mathrm{OH} \mathrm{R} \mathrm{R}_{2}=\mathrm{H}$

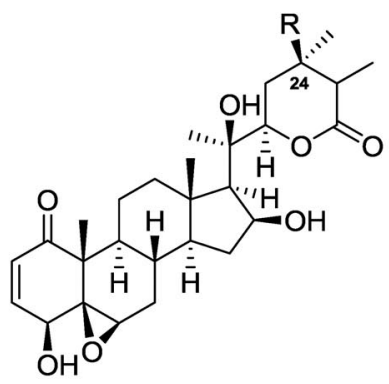

$59 \mathrm{R}=\mathrm{H}$

$60 \mathrm{R}=\mathrm{OH}$

Fig. 4 Withanolides used for SARA in Table 3 (analysis from literature sources).

(continues on next page) 


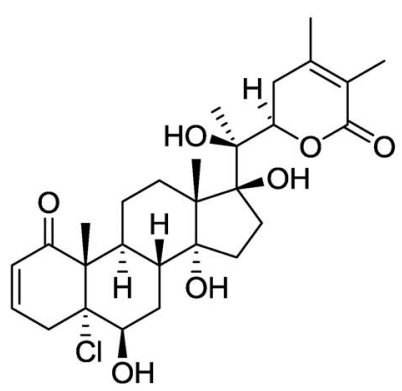

61

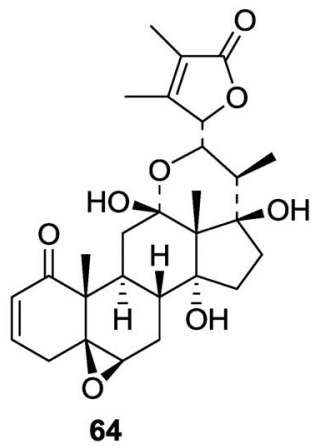

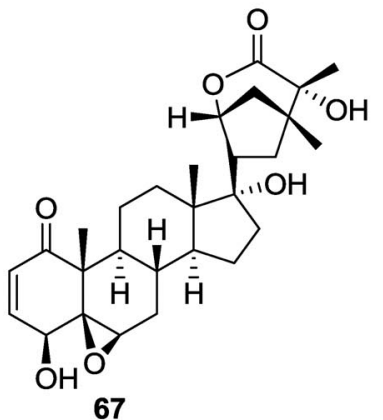

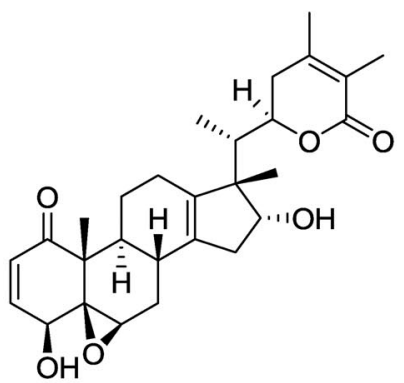

70

Fig. 4 (Continued)

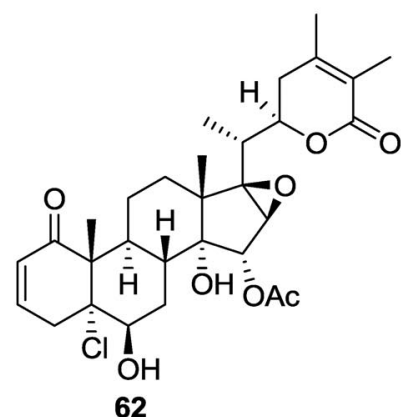<smiles>CC1=C(C)C(=O)OC1</smiles>

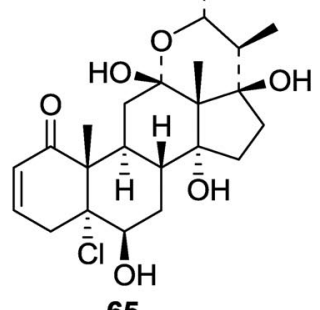

65

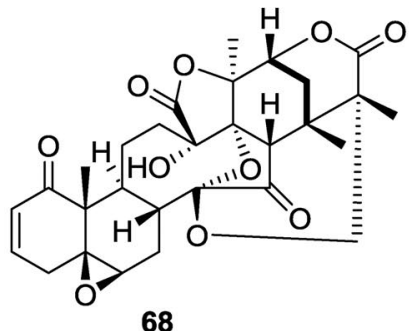

68<smiles>CC(=O)O[C@H]1C=C([C@H](C)C2CC(C)=C(C)C(=O)O2)[C@]2(C)CCC3[C@](C)(C[C@H](O)[C@@]4(Cl)CC=CC(=O)[C@@]34C)[C@H]12</smiles>

63
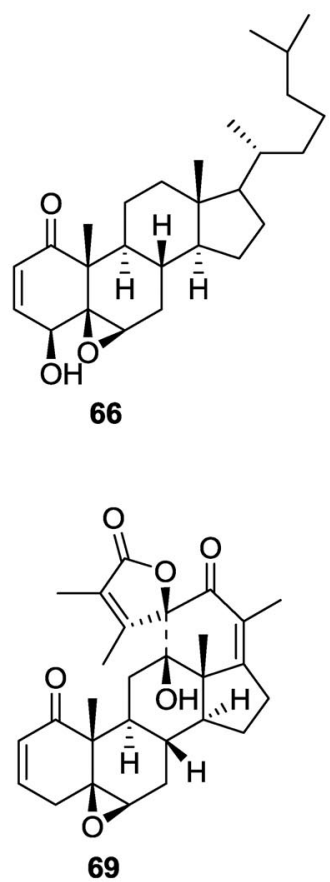


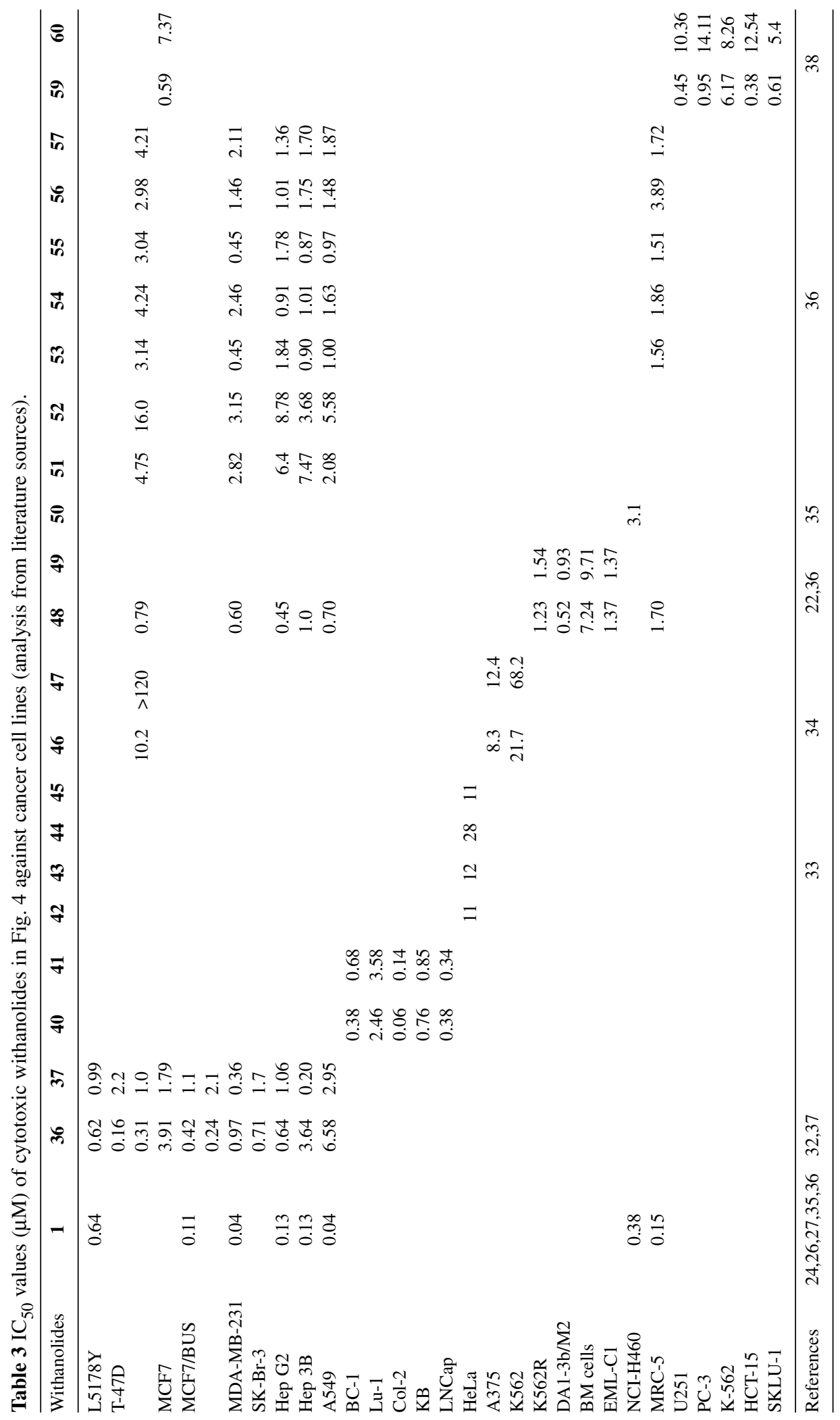

(C) 2012, IUPAC

Pure Appl. Chem., Vol. 84, No. 6, pp. 1353-1367, 2012 
ative screening data are not available in order to evaluate the significance of the presence of the $-\mathrm{OH}$ or -OR groups at such positions.

In addition, it has been reported that when the $5 \beta, 6 \beta$-epoxy moiety in ring $\mathrm{B}$ is replaced by $5 \alpha$-chloro-6 $\beta$-hydroxy-functionality, the cytotoxicity of the two withanolides was comparable and in most cases the activity increased in the presence of the latter functional array. Several pairs of withanolides were compared for their activities, and similar results could be found in the literature: withanolide C 61 and withanolide E 36 [26]; physagulin I 62 and physagulin H 42 [38]; physagulin B 63 and 4-deoxy-withangulatin A 44 [38]; physagulin B 63 and withangulatin 45 [40]; and trechonolide A 64 and jaborosalactone 4265 [27].

Side chain: Withaferin A 1, withanolide D 48, withanolide E 36, and 4 $\beta$-hydroxywithanolide E 37 bearing a $\delta$-lactone in the nine-carbon side chain are more cytotoxic than the synthetic analogue, $5,6 \beta$-epoxy-4 $\beta$-hydroxy-5 $\beta$-cholest-2-en-1-one 66 [24]. Tubocapsanolide F 57 with a $\delta$-lactone in the side chain was shown to be more potent than anomanolide A 67 with a type XIV skeleton [36], suggesting the importance of a $\delta$-lactone in order to retain cytotoxic potency.

Structural types: $4 \beta, 14 \alpha$-Dihydroxywithanolide E 38 with an unmodified skeleton was more potent than physalin F $\mathbf{6 8}$ with a type XIX skeleton and physanolide A with a type XVII framework [25]. Withanolide E 36 was more potent than jaborosalactone 169 with a type XVI skeleton. Tubocapsenolide A $\mathbf{7 0}$ with a $\delta$-lactone in the side chain showed strong cytotoxicity comparable to that of withanolide D 48 [36]. From these observations, it seems that type I withanoides with a lactone present in the nine-carbon side chain showed the most potent cytotoxic activity among the diverse variants discussed here.

In summary, the SARA derived from our own study and from data obtained from the literature confirmed that the $5 \beta, 6 \beta$-epoxy-group or $5 \alpha$-chloro- $6 \beta$-hydroxy-functionality in ring B, and conjugated $\Delta^{2}$-1-oxo-functionality in ring $\mathrm{A}$ are the important requirements for the enhancement of antiproliferative activities in various cell systems. The unmodified type I withanolides showed more potent cytotoxicity than the other structural types analyzed to date. Based on these observations, it is suggested that the $-\mathrm{OH}$ or $-\mathrm{OR}$ groups at $\mathrm{C}-4,7,11,12,14,15,16,17,18,19,20,23,24$, and 27 are non-contributors to the antiproliferative activity. In most cases, withanolides possessing -OH or -OR groups at such positions are slightly less potent than those lacking the $-\mathrm{OH}$ or $-\mathrm{OR}$ groups. Furthermore, glycosylation of withanolides decreased the cytotoxic effect while esterification of the hydroxyl groups reversed the effect by increasing cytotoxicity (Fig. 5).

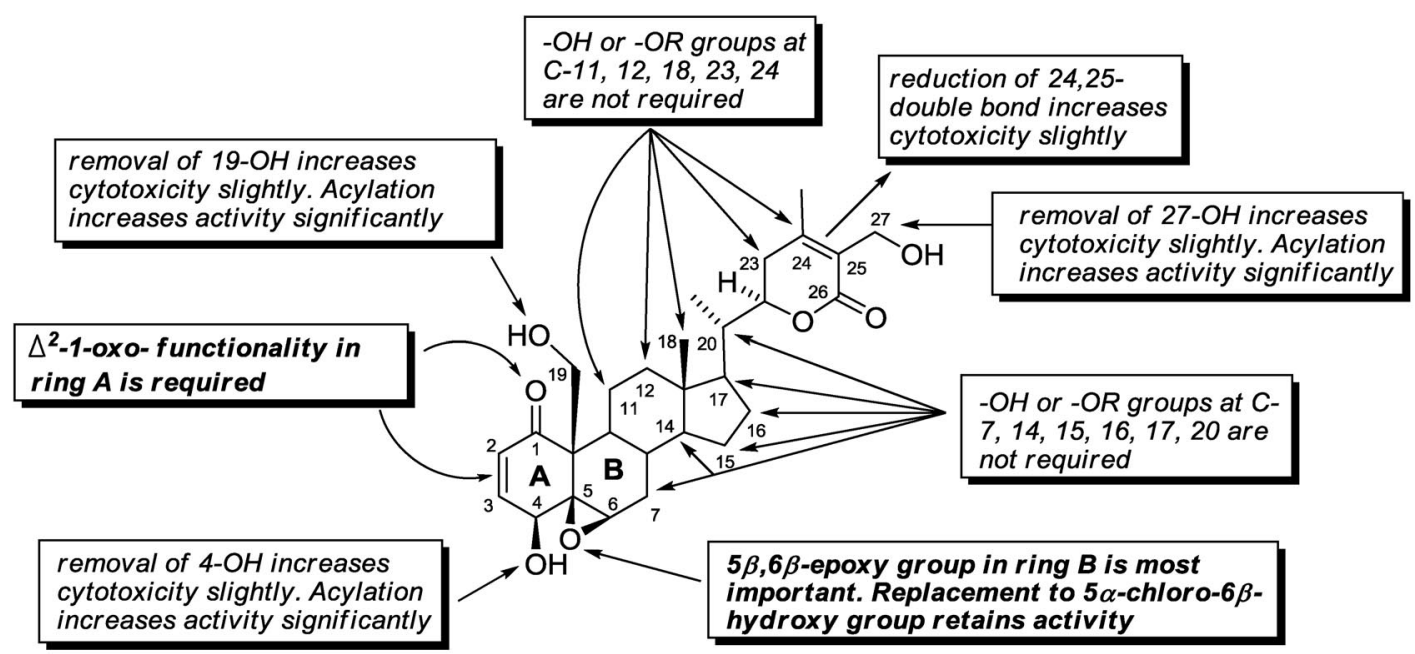

Fig. 5 SARA of withanolides. 


\section{ACKNOWLEDGMENTS}

This study was supported, in part, by grant IND 0061464 (awarded to B.N.T.) from the Kansas Bioscience Authority (KBA) and Center for Heartland Plant Innovations (HPI). The authors also acknowledge partial financial assistance from grant NFP0066367 from the Institute for Advancing Medical Innovation (IAMI) (awarded to M.S.C. and to B.N.T.). Partial support for the in vitro experiments was provided by the University of Kansas Center for Cancer Experimental Therapeutics NIHCOBRE P20 RR015563 (PI: B.N.T., project award PI: M.S.C.).

\section{REFERENCES}

1. D. Lavie, E. Glotter, Y. Shvo. J. Org. Chem. 30, 1774 (1965).

2. E. Glotter. Nat. Prod. Rep. 8, 415 (1991).

3. A. B. Ray, M. Gupta. Prog. Chem. Org. Nat. Prod. 63, 1 (1994).

4. A. S. R. Anjaneyulu, D. S. Rao, P. W. Lequesne. Studies in Natural Products Chemistry, Atta-urRahman (Ed.), Vol. 20, pp. 135-261, Elsevier Science, Amsterdam (1998).

5. A. S. Veleiro, J. C. Oberti, G. Burton. Studies in Natural Products Chemistry, Atta-ur-Rahman (Ed.), Vol. 32, pp. 1019-1052, Elsevier Science, Amsterdam (2005).

6. E. Eich. Solanaceae and Convolvulaceae: Secondary Metabolites, p. 466, Springer-Verlag, Berlin (2008).

7. L. X. Chen, H. He, F. Qiu. Nat. Prod. Rep. 28, 705 (2011).

8. R. I. Misico, V. E. Nicotra, J. C. Oberti, G. Barboza, R. R. Gil, G. Burton. Prog. Chem. Org. Nat. Prod. 94, 127 (2011).

9. R. D. Budhiraja, P. Krishan, S. Sudhir. J. Sci. Ind. Res. 59, 904 (2000).

10. R. C. Almeida-Lafetá, M. J. P. Ferreira, V. P. Emerenciano, M. A. C. Kaplan. Helv. Chim. Acta 93, 2478 (2010).

11. D. Cardona, W. Quiñones, F. Torres, I. D. Vélez, C. I. Orozco-P, J. Garzón, F. Echeverri. Actual. Biol. 27, 81 (2005).

12. R. K. Suleiman, M. A. Zarga, S. S. Sabri. Fitoterapia 81, 864 (2010).

13. K. H. Kim, S. U. Choi, S. Z. Choi, M. W. Son, K. R. Lee. J. Agric. Food Chem. 59, 6980 (2011).

14. P. S. Vankar, J. Srivastava, K. Molčanov, B. Kojic-Prodić. Phytochem. Lett. 2, 67 (2009).

15. C. H. Chao, K. J. Chou, Z. H. Wen, G. H. Wang, Y. C. Wu, C. F. Dai, J. H. Sheu. J. Nat. Prod. 74, 1132 (2011).

16. M. B. Ksebati, F. J. Schmitz. J. Org. Chem. 53, 3926 (1988).

17. A. K. Samadi, X. Tong, R. Mukerji, H. Zhang, B. N. Timmermann, M. S. Cohen. J. Nat. Prod. 73, 1476 (2010).

18. S. M. Kupchan, W. K. Anderson, P. Bollinger, R. W. Doskotch, R. M. Smith, J. A. S. Renauld, H. K. Schnoes, A. L. Burlingame, D. H. Smith. J. Org. Chem. 34, 3858 (1969).

19. J. Sun, M. A. Blaskovich, R. Jove, S. K. Livingston, D. Coppola, S. M. Sebti. Oncogene 27, 1344 (2008).

20. S. K. Chakraborti, B. K. De, T. Bandyopadhyay. Experientia 30, 852 (1974).

21. C. P. Cordero, S. J. Morantes, A. Páez, J. Rincón, F. A. Aristizábal. Fitoterapia 80, 364 (2009).

22. V. Roumy, M. Biabiany, T. Hennebelle, E. M. Aliouat, M. Pottier, H. Joseph, S. Joha, B. Quesnel, R. Alkhatib, S. Sahpaz, F. Bailleul. J. Nat. Prod. 73, 1313 (2010).

23. S. Mondal, C. Mandal, R. Sangwan, S. Chandra, C. Mandal. Mol. Cancer 9, 239 (2010).

24. M. Yoshida, A. Hoshi, K. Kuretani, M. Ishiguro, N. Ikekawa. J. Pharm. Dyn. 2, 92 (1979).

25. A. G. Damu, P. C. Kuo, C. R. Su, T. H. Kuo, T. H. Chen, K. F. Bastow, K. H. Lee, T. S. Wu. J. Nat. Prod. 70, 1146 (2007).

26. Y. H. Lan, F. R. Chang, M. J. Pan, C. C. Wu, S. J. Wu, S. L. Chen, S. S. Wang, M. J. Wu, Y. C. Wu. Food Chem. 116, 462 (2009). 
27. R. P. Machin, A. S. Veleiro, V. E. Nicotra, J. C. Oberti, J. M. Padrón. J. Nat. Prod. 73, 966 (2010).

28. X. Tong, H. Zhang, B. N. Timmermann. Phytochem. Lett. 4, 411 (2011).

29. H. Zhang, A. K. Samadi, J. J. Araya, R. J. Gallagher, X. Tong, V. W. Day, M. S. Cohen, K. Kindscher, R. Gollapudi, B. N. Timmermann. J. Nat. Prod. 74, 2532 (2011).

30. Y. M. Xu, M. T. Marron, E. Seddon, S. P. McLaughlin, D. T. Ray, L. Whitesell, A. A. L. Gunatilaka. Bioorg. Med. Chem. 17, 2210 (2009).

31. B. Jayaprakasam, Y. Zhang, N. P. Seeram, M. G. Nair. Life Sci. 74, 125 (2003).

32. S. Minguzzi, L. E. S. Barata, Y. G. Shin, P. F. Jonas, H. B. Chai, E. J. Park, J. M. Pezzuto, G. A. Cordell. Phytochemistry 59, 635 (2002).

33. S. Nagafuji, H. Okabe, H. Akahane, F. Abe. Biol. Pharm. Bull. 27, 193 (2004).

34. B. Chataing, A. Usubillaga, C. M. Pérez, R. Méndez. Ciencia 17, 113 (2009).

35. M. I. Choudhary, S. Hussain, S. Yousuf, A. Dar, Mudassar, Atta-ur-Rahman. Phytochemistry 71, 2205 (2010).

36. P. W. Hsieh, Z. Y. Huang, J. H. Chen, F. R. Chang, C. C. Wu, Y. L. Yang, M. Y. Chiang, M. H. Yen, S. L. Chen, H. F. Yen, T. Lübken, W. C. Hung, Y. C. Wu. J. Nat. Prod. 70, 747 (2007).

37. S. Minguzzi, L. E. S. Barata, G. A. Cordell. Quim. Nova 34, 237 (2011).

38. E. Maldonado, A. L. Pérez-Castorena, C. Garcés, M. Martínez. Steroids 76, 724 (2011).

39. A. B. Ray. J. Indian Chem. Soc. 75, 672 (1998).

40. Q. P. He, L. Ma, J. Y. Luo, F. Y. He, L. G. Lou, L. H. Hu. Chem. Biodiv. 4, 443 (2007). 